\title{
Sosialisasi Budaya Organisasi di Pondok Pesantren Muhammadiyah: Studi Kasus Sosialisasi Budaya Organisasi di Pendidikan Ulama Tarjih Muhammadiyah
}

\author{
Oleh: Muhammad Najih Farihanto \\ Program Studi Ilmu, Komunikasi Universitas Ahmad Dahlan
}

\begin{abstract}
Abstrak
Sosialisasi budaya organisasi menjadi bagian yang wajib dilakukan bagi pengelola organisasi dalam penguatan nilai-nilai budaya organisasi. Robbins (2003) mengatakan terdapat tiga tahap dalam sosialisasi budaya organisasi yaitu tahap prakedatangan, tahap pertemuan, dan tahap metamorfosis. Dalam penelitian ini, teori sosialisasi budaya organisasi tersebut diujikan dalam organisasi pondok pesantren Muhammadiyah yaitu Pendidikan Ulama Tarjih Muhammadiyah (PUTM). Dalam penelitian ini menghasilkan fakta bahwa teori sosialisasi budaya organisasi yang dikemukakan oleh Robbins dapat direalisasikan di PUTM. Dalam penelitian ini juga membahas tentang berbagai temuan tentang fenomena komunikasi yang terjadi dalam sosialisasi budaya organisasi di PUTM. Penelitian ini menggunakan studi kasus, agar lebih terfokus kepada objek kajian serta mampu menjelaskan objek-objek di sekitar kajian. Juga dalam makalah ini menggunakan motode wawancara, penelususan dokumen dan observasi langsung dalam proses pengumpulan data.
\end{abstract}

Kata kunci: Sosialisasi, Budaya Organisasi, Pondok Pesantren

\section{A. Latar Belakang}

Budaya organisasi menurut Sarplin merupakan suatu system nilai, kepercayaan dan kebiasaan dalam suatu organisasi yang saling berinteraksi dengan struktur system formalnya untuk menghasilkan norma-norma perilaku organisasi. Sementara itu menurut Luthan budaya organisasi merupakan norma-norma dan nilai-nilai yang mengarahkan perilaku anggota organisasi. Setiap anggota berprilaku sesuai dengan budaya yang berlaku agar diterima oleh lingkungannya (Laksmini, 2010: 7).

Dalam penanaman dan penguatan budaya organisasi diperlukan aktifitas sosialisasi. Sosialisasi mencakup kegiatan di mana anggota mempelajari seluk beluk organisasi serta bagaimana mereka harus berinteraksi dan berkomunikasi antara anggota organisasi untuk menjalankan aktifitas organisasi. Menurut Laksmini (2010: 41) tujuan sosialisasi dari budaya organisasi adalah membentuk suatu sikap dasar kebiasaan dan nilainilai yang dapat memupuk kerja sama, integritas dan komunikasi dalam organisasi. Selain itu tujuan dari sosialisasi budaya organisasi adalah memperkenalkan budaya orgnisasi pada anggota dan meningkatkan komitmen dan daya inovasi anggota. Dalam sosialisasi budaya organisasi, Robbins (2003) berpendapat bahwa sosialisasi budaya orgainisasi melawati tiga tahap. Tahap yang pertama adalah prakedatangan merupakan waktu pembelajaran dalam proses sosialisasi yang terjadi sebelum seorang anggota baru bergabung dalam organisasi.Tahap kedua adalah perjumpaan suatu proses sosialisasi. Di organisasi ini 
seorang anggota baru melihat seperti apa sebenarnya organisasi yang dimasukinya. Tahap ketiga yaitu metamorfosis, pada tahap ini anggota baru menyesuaikan diri pada nilai-nilai dan norma kelompok kerjanya.

Muhammadiyah dikenal sebagai organisasi Keislaman yang modern memiliki sebuah lembaga pendidikan berpa pondok pesantren khusus dibuat untuk mencetak para kader ulama yang handal dalam bidang ketarjihan yaitu Pendidikan Ulama Tarjih Muhammadiyah (PUTM). Sebagai organisasi pencetak kader ulama, PUTM memiliki budaya organisasi yang khas dan menjadi identitas organisasi.Menurut Alma, salah satu santri atau thalabah PUTM, Budaya di PUTM yang sangat kental antara lain wajib bangun setiap malam (kecuali malam Jum'at) untuk melakukan salat tahajud, setiap Senin dan Kamis wajib puasa sunah, memakai peci setiap salat, memakai baju lengan panjang ketika salat, dan beberapa nilai yang lain yang sudah menjadi kebiasaan PUTM semenjak dahulu. ${ }^{1}$.

Dari teori dan data awal di atas, muncul pertanyaan dari penulis, apakah tahap sosialisasi yang disampaikan oleh Robbins juga terjadi di PUTM. Karena menurut pandangan peneliti, berdasarkan beberapa refrensi tentang budaya organisasi yang pernah peneliti baca, penelitian tentang budaya organisasi yang dilakukan para ilmuan sebagian besar dilakukan di perusahaan atau organisasi profite. Lalu bagaimana dengan penelitian tentang sosialisasi budaya organisasi di lembaga pondok pesantren seperti PUTM. Maka dari itu, penelitian ini membahas secara mendalam tentang bagaimana sosialisasi budaya organisasi di PUTM.

\section{B. Tinjauan Teori}

Budaya organisasi merupakan suatu budaya yang dimiliki suatu organisasi. Namun budaya bukan sekedar kebiasaan atau perilaku yang relatif atau perilaku rata-rata (moderate behaviour) melainkan sebagai suatu karateristik yang unik dari suatu organisasi. Budaya dalam hal ini merupakan faktor yang memberikan spirit bagi organisasi dan membedakan dengan organisasi lain. Budaya organisasi merupakan metafora untuk menggambarkan norma, perasaan, dan pola-pola aktivitas suatu kelompok. Budaya organisasi merupakan iklim komunikasi yang berakar pada seperangkat norma yang sama. Budaya organisasi meliputi pemikiran kelompok, cara mengintepretasikan dan mengorganisasikan tindakan anggota organisasi (Liliweri, 2004: 326).

Menurut Robbins (2003) salah satu kekuatan dalam memainkan peranan yang penting dalam mempertahankan suatu budaya adalah sosialisasi. Sosialisasi adalah suatu proses yang mangadaptasikan anggota organisasi pada budaya organisasi tersebut. Sementara menurut Kreitner dan Kinicki (2003: 96) sosialisasi didefinisikan sebagai proses seseorang mempelajari nilai, norma, dan perilaku yang dituntut, yang memungkinkan ia untuk berpartisipasi sebagai anggota organisasi. Secara singkat sosialisasi organisasi mengubah orang baru menjadi orang yang berfungsi penuh dalam mempromosikan dan mendukkung nilai dan keyakinan dasar organisasi. Begitu pula dalam organisasi PUTM,

${ }^{1}$ Personal dengan Alma Febriana F. ThalabahPUTM. 25 April 2013. Dengan gayanya yang sedikit urakan, Alma menceritakan pengalamannya selama tiga tahun tinggal di PUTM,. Wawancara dilakukan di Warung Kopi Blandongan, Banguntapan. 
Diterbitkan oleh Program Studi Ilmu Komunikasi

Universitas Ahmad Dahlan Yogyakarta

dalam menguatkan budaya organisasi pada anggota terutama anggota baru, perlu dilakukan sosialisasi budaya organisasi demi terwujudnya tujuan organisasi.

Menurut Robbins (2003). Sosialisasi dikonsepkan sebagai seuatu proses yang terdiri dari tiga tahap, yaitu:

1. Tahap pertama yang disebut dengan tahap prearrival atau prakedatangan, merupakan waktu pembelajaran dalam proses sosialisasi yang terjadi sebelum seorang anggota baru bergabung dalam organisasi, dengan kata lain proses ini terjadi sebelum anggota organisasi bergabung dengan organisasi. Mereka datang dengan serangkaian nilainilai, sikap dan tuntutan yang sudah ada.

2. Tahap kedua adalahencounter atau perjumpaan suatu proses sosialisasi. Di organisasi ini seorang anggota baru melihat seperti apa sebenarnya organisasi yang dimasukinya. Pada proses ini individu kemungkinan akan menghadapi perbedaan antara harapan dengan kenyataan.

3. Tahap ketiga yaitu metamorfosis, pada tahap ini anggota baru menyesuaikan diri pada nilai-nilai dan norma kelompok kerjanya, dengan kata lain pada tahap ini anggota baru harus menyelesaikan berbagai permasalahan yang ditemui selama masa perjumpaan.

Ketiga proses sosialisasi seperti di atas, akan berpengaruh pada produktivitas kerja, komitmen organisasi dan tingkat keluar masuknya anggota organisasi. Robbins (2003) mengatakan suatu usaha individu dalam suatu organisasi dalam proses sosialisasi yang dilakukan secara bertahap yang dimulai dengan prakedatangan yang kemudian dilanjutkan dengan proses perjumpaan dimana setiap individu akan dihadapkan proses untuk dapat menyesuaikan diri pada nilai-nilai yang ada di organisasi. Dengan proses sosialisasi yang dilakukan oleh setiap anggota PUTM diharapkan setiap anggota dapat menyesuaikan diri dengan budaya organisasi yang baru sehingga setiap anggota organisasi dapat melihat dampak dari proses sosialisasi yang dilakukan apakah akan semakin meningkatkan komitmen dan produktifitas anggota organisasi atau justru akan membuat anggota organisasi keluar dari organisasi karena nilai-nilai yang tidak sesuai dengan norma kelompok atau nilai-nilai organisasi.

Dalam proses sosialisasi budaya organisasi terdapat interaksi yang terjadi antar anggota organisasi. Interaksi yang terjadi dalam organisasi disebut sebagai komunikasi organisasi. Secara umum komunikasi organisasi dapat dibedakan atas komunikasi formal dan komunikasi informal. Komunikasi formal salurannya ditentukan oleh struktur yang telah direncanakan dan tidak dapat dipungkiri oleh organisasi. Bila pesan mengalir melaui jalur resmi yang ditentukan oleh hierarki resmi organisasi atau oleh fungsi pekerjaan maka pesan itu berada dalam jalur komunikasi formal. Adapun fungsi penting sistem komunikasi formal menurut Liliweri (1997: 284) adalah sebagai berikut:

1) Komunikasi formal terbentuk sebagai fasilitas untuk mengkoordinir kegiatan pembagian kerja dalam organisasi.

2) Hubungan formal secara langsung hanya meliputi hubungan antara atasan dengan bawahan. Komunikasi langsung seperti ini memungkinkan dua pihak untuk berpartisipasi umpan balik secara cepat.

3) Komunikasi formal memungkinkan anggota dapat mengurangi atau menekankan waktu yang akan terbuang, atau kejenuhan produksi, mengeliminir ketidak pastian operasi pekerjaan, termasuk tumpang tindih 
tugas dan fungsi, serta pembaharuan menyeluruh yang berdampak pada efektivitas dan efisiensi.

4) Komunikasi formal menekankan terutama pada dukungan yang penuh dan kuat dari kekuasaan maelalui struktur dan hierarkis.

Bentuk jaringan komunikasi vertikal terdiri atas vertikal dari atas dan dari bawah. Menurut Lewis (dalam Muhammad, 2007: 108), komunikasi vertical kebawah adalah untuk menyampaikan tujuan, untuk merubah sikap, membentuk pendapat, mengurangi ketakutan dan kecurigaan yang timbul karena salah informasi, mencegah kesalahpahaman karena kurang informasi dan mempersiapkan anggota organisasi untuk menyesuaikan diri dengan perubahan.

Sementara itu komunikasi dari bawah ke atas (bottom up) adalah pesan yang mengalir daru bawahan kepada atasan atau dengan kata lain komunikasi yang terjadi dari tingkat yang lebih rendah kepada tingkat yang lebih tinggi. Tujuan komunikasi ini adalah untuk memberikan balikan, memberikan saran dan mengajukan pertanyaan. Komunikasi ini mempunyai efek pada penyempurnaan moral dan sikap bawahan, tipe pesan adalah integrasi dan pembauran (Muhammad, 2007: 116-117).

Betuk komunikasi formal yang selanjutnya adalah komunikasi horizontal adalah pertukaran pesan di antara orang-orang yang sama tingkat otoritasnya di dalam organisasi (Muhammad, 2007).Pace dan Faules (2010: 95) mengatakan bahwa fungsi dari komunikasi horisontal adalah untuk saling memberikan informasi dalam perencanaan dan berbagai aktifitas. Ide dari banyak orang biasanya akan lebih baik dari pada ide satu orang. Oleh karena itu komunikasi horisontal sangat diperlukan untuk mecari ide yang lebih baik.

Sedangkan komunikasi informal tidaklah direncanakan dan biasanya tidaklah mengikuti struktur formal organisasi, tetapi timbul dari interaksi sosial yang wajar di antara anggota organisasi (everyday talk). Seperti yang disampaikan oleh Pace dan Faules (2010:199) komunikasi informal terjadi ketika anggota organisasi berinteraksi dengan yang lainnya tanpa memperhatikan posisi mereka dalam organisasi dan pengarahan arus informasi bersifat pribadi. Hubungan paling intim yang individu miliki dengan anggota yang lain dalam tingkat pribadi, antara teman dan juga dengan hirarki yang ada diatasnya. Jaringan komunikasi lebih dikenal sebagai desas-desus (grapvine) atau kabar angin. Informasi yang mengalir dalam jaringan grapvine ini, kelihatannya berubah-ubah dan tersembunyi. Dalam istilah komunikasi, grapvine dikatakan sebagai metode untuk menyampaikan rahasia dari orang ke orang yang tidak dapat diperoleh melalui jaringanjaringan komunikasi formal. Komunikasi informal cenderung berisi laporan rahasia mengenai kejadian-kejadian yang tidak mengalir resmi. Informasi yang diperoleh dari desas-desus adalah yang berkenaan dengan apa yang didengar atau apa yang dikatakan orang dan bukan apa yang diumumkan oleh yang berkuasa.

Walaupun grapvineitu membawa informasi yang informal tetapi ada manfaatnya bagi organisasi. Grapvine memberikan balikan kepada pimpinan mengenai sentimen bawahan. Dengan adanya jaringan komunikasi informal bawahan dapat menyalurkan ekspresi emosional dari pesan-pesan yang dapat mempercepat permusuhan dan rasa marah bila ditekan, grapvine dapat membantu menerjemahkan pengarahan pimpinan ke dalam bahasa yang lebih mudah dipahami oleh anggota organisasi (Muhammad, 2007). 
Diterbitkan oleh Program Studi IImu Komunikasi

Universitas Ahmad Dahlan Yogyakarta

Salah satu komunikasi organisasi yang paling nyata adalah konsep hubungan. Goldhaber mendefinisikan organisasi "sebuah hubungan yang saling bergantung (Pace dan Faules 2010:202). Bila satu dengan yang lain saling bergantung, ini berarti satu dengan yang lain saling mempengaruhi. Pola dan sifat dalam suatu organsiasi dapat ditentuka oleh stuktur atau hubungan posisional dan hubungan antar personal dimana individu-individu dalam organisasi bertindak di luar struktur peran sehingga menciptakan jariangn komunikasi informal.

Keintiman hubungan yang kita miliki dengan orang lain dalam tingkat pribadi, antara teman, rekan sebaya biasanya disebut sebagai hubungan antar persona. Teman dekat cenderung memperhatikan dari pada yang lainya. "Dengan mereka kita mendapatkan hubungan antar persona yang saling memuaskan. Dengan mereka kita beresonansi, bergetar, dan sesuai, membuktikan bahwa mereka memperhatikan kita" (Pace dan Faules, 2010:202).

\section{Desain penelitian}

Penelitian ini merupakan penelitian diskripstif kualitatif. Peneliti ingin menggambarkan secara alami tentang keadaan dengan tidak menggunakan hipotesis. Penelitian ini bertujuan untuk memberikan gambaran tentang sosialisasi budaya organsiasi di PUTM. Melalui metode diskriptif akan mampu memaparkan fenomena secara rinci serta menghadirkan analisis yang lebih mendalam yang tidak mampu diungkapkan dengan metode kuantitatif.

Penelitian ini menggunakan studi kasus karena mengangkat masalah empiris mengenai suatu kasus. Hal ini dimaksudkan agar lebih terfokus kepada objek kajian serta mampu menjelaskan objek-objek di sekitar kajian. Studi kasus merupakan suatu pendekatan untk mempelajari, menerangkan atu mengintepretasi suatu "kasus" dalam konteksnya yang alami tanpa ada intervensi dari pihak luar (Baedowi dalam Agus Salim, 2006: 118). Studi kasus ini daat dilakukan ketika peneliti ingin memahami atau menjelaskan suatu fenomena tertentu (Wimmer dan Dominick, 2006: 136).

Studi kasus adalah pendekatan yang bisa secara detail memberikan gambaran mengenai latar belakang sifat dan suatu peristiwa. Dalam penelitian ini, bentuk pertanyaan utama yang diajukan adalah "bagaimana", yang sangat cocok dengan pendekatan studi kasus. Wimmer dan Dominick (2006: 138) menjelaskan: the case study is most appropriate for quoestions that begin with "how" or "why". Yin (2004: 13) menjelaskan bahwa pertanyaan "bagaimana" akan diarahkan pada serangkaian peristiwa kontemporer di mana hanya memiliki sedikit peluang untuk melakukan kontrol terhadap peristiwa tersebut.

Pengumpulan data dalam penelitian ini hanya menggunakan sebagian teknik saja sesuai dengan jangkauan penelitian yang hendak dicapai dan relevansinya dengan rumusan masalah. Tiga cara yang dilakukan untuk menumpulkan data guna kepentingan penelitian ini yaitu wawancara, observasi langsung dan penelusuran dokumen.

Data yang telah diperoleh kemudian dipelajari dan dikaji ulang dengan penyesuaian-penyesuaian dari keseluruahn data, baik dari wawancara, dokumentasi dan observasi langsung, agar sinkronisasi data ditemukan dan memepermudah pelaksanaan penelitian hingga pada tahap pelaporan. 


\section{Hasil Penelitian}

\section{Budaya Organisasi PUTM}

Pendidikan Ulama Tarjih Muhammadiyah (PUTM) adalah bagian dari gerakan amal usaha Muhammadiyah yang mempunyai program khusus, yaitu mendidik dan mempersiapkan ulama' Tarjih Muhammadiyah yang memiliki kompetensi utama dalam mengembangkan keilmuan pada tafaqquh fid-din (memperdalam pemahaman agama), keulamaan, dakwah, pendidikan dan kepemimpinan Islami, yang mampu mengintegrasikan ilmu dan amal. Maka para thalabah akan diberikan berbagai macam keahlian yang bersifat multidisipliner dan juga interdisipliner. Maka dari itu, Lulusan dari PUTM diharapkan memiliki kualifikasi sebagai berikut:

a. Menjadi Sarjana muslim yang beriman dan bertaqwa, berakhlak mulia, yang mempunyai kemampuan akademik, professional dan beramal menuju terwujudnya masyarakat Islam yang sebenar-benarnya.

b. Menjadi kader ulama dan pemimpin yang berkepribadian Muhammadiyah.

c. Mampu mengembangkan dan menyebarluaskan risalah Islamiyah dalam rangka li'ilaa'I kalimatillah dan meningkatkan kesejahteraan umat manusia.

d. Menguasai dasar-dasar ilmiah dan pengetahuan serta wawasan yang luas tentang ketarjihan, sehingga mampu menentukan, memahami, menjelaskan dan merumuskan cara pengambilan keputusan dan penyelesaian masalah yang dihadapinya.

e. Mampu mengikuti perkembangan ilmu pengetahuan dan teknologi.

Untuk mewujudkan tujuan PUTM dibutuhkan nilai-nilai yang melembaga yang dapat membantu tercapainya cita-cita organisasi. nilai yang melembaga tersebut adalah budaya organisasi. Budaya organisasi merupakan suatu budaya yang dimiliki suatu organisasi. Namun budaya bukan sekedar kebiasaan atau perilaku yang relatif atau perilaku rata-rata (moderate behaviour) melainkan sebagai suatu karateristik yang unik dari suatu organisasi. Budaya dalam hal ini merupakan faktor yang memberikan spirit bagi organisasi dan membedakan dengan organisasi lain. Budaya organisasi merupakan metafora untuk menggambarkan norma, perasaan, dan pola-pola aktivitas suatu kelompok. Budaya organisasi merupakan iklim komunikasi yang berakar pada seperangkat norma yang sama. Budaya organisasi meluputi pemikiran kelompok, cara mengintepretasikan dan mengorganisasikan tindakan anggota organisasi (Liliweri, 2004: 326).

Prilaku relatif yang merupakan karakteristik yang unik peneliti temukan dalam budaya organisasi di PUTM. Sebagai lembaga pendidikan keagamaan yang mencetak para ulama tarjih Muhammadiyah, PUTM memiliki karakteristik yang tidak dimiliki oleh lembaga lain. Sebagai musyrif, Hudzaifaturrahman (Udze) menjelaskan karakteristik yang membedakan PUTM dengan Perguruan Tinggi yang lain-khususnya dalam lingkungan Muhammadiyah adalah perhatian besarnya dalam hal membaca kitab kuning atau gundul; yang menurut penuturan dari para founding father PUTM berfungsi sebagai mabda' awal (prinsip dasar) dalam memahami ajaran Islam yang notabenenya sumber atau rujukan pokoknya adalah dari kitab-kitab gundul yang berbahasa arab. Ini salah satu sisi intelektual yang harus dicapai oleh PUTM. Sisi lain dari PUTM juga berusaha membekali Thalabahnya dengan keilmuan-keilmuan agama terutama yang berkaitan dengan 
Diterbitkan oleh Program Studi IImu Komunikasi

Universitas Ahmad Dahlan Yogyakarta

ketarjihan dan ilmu-ilmu pokok seperti ilmu nahwu sharaf, ushul fiqih, hadits dan ulumul Quran $^{2}$.

Untuk mencetak kader ulama yang beriman, bertaqwa, dan berakhlak mulia, PUTM mengedepankan sisi ibadah dan perilaku yang ditanamkan kepada para thalabah. Dijelaskan oleh Udze, bahwa dengan penguatan ibadah dan perilaku dapat mencerminkan seorang ulama tarjih yang dapat memberikan contoh bagi masyarakat.

Oleh karen itu untuk menguatkan nilai tersebut, PUTM melalui para pendamping membiasakan para thalabahnya untuk melaksanakan rutinitas yang mencerminkan sifat ulama yaitu shalat tahajjud, shalat dhuha, puasa senin kamis, dan juga menjaga akhlakul karimah. Selain itu, PUTM juga membiasakan para thalabahnya berpakaian yang mencerminkan karakter seorang ulama tarjih Muhammadiyah. Hal ini dijelaskan oleh Endi yang sudah lebih dari enam tahun berada di PUTM.

“..contohnya dalam hal berpakian, ciri khas anak PUTM berpeci hitam, lengan panjang, tidak mengenakan lengan pendek dan kaos pada saat perkuliahan dan shalat. Contohnya lain dari kebiasaan yang sudah turun temurun adalah mengenakan seragam atau jas almamater selama perkuliahan. Kita menyebut peraturan ini sebagai sunnah pondok, ada beban moral tersendiri apabila kita tidak mengikuti apa yang sudah menjadi kebiasaan dari PUTM walaupun tidak tertulis dalam peraturan".

(Endi. Alumni dan bagian keuangan PUTM. 4 juli 2013)

Hal yang serupa juga disampaikan oleh Alma, mahasiswa PUTM tingkat akhir ini menjelaskan bahwa PUTM memiliki sunah pondok yaitu tradisi yang ada di PUTM. Tradisi tersebut sudah ada di PUTM sejak dulu. Sebenarnya tidak ada kewajiban dalam melaksanakan sunah pondok, seperti mengenakan baju lengan panjang ketika shalat. Tetapi kalau thalabah akan merasa risih sendiri ketika mengenakan baju lengan pendek pada saat shalat $^{3}$.

\section{Sosialisasi Budaya Organisasi PUTM}

Sosialisasi budaya organisasi dimulai dari masa prakedatangan dimana merupakan waktu pembelajaran dalam proses sosialisasi yang terjadi sebelum thalabah baru mendjadi calon atau sebelum bergabung dalam Organiasasi (Robbins, 2003). Dalam masa pra kedatangan ini, peneliti mendapat beragam informasi dari beberapa informan. Riduan Hadi Pranata (Riduan) yang meruapakan alumni PUTM mengatakan bahwa tidak pernah terpikir olehnya untuk menimba ilmu di PUTM. Awalnya Riduan hanya mencoba-coba karena tergiur oleh tawaran yang menyebutkan bahwa belajar di PUTM tidak dipungut biaya, bahkan dia tidak pernah mengira PUTM mempunyai budaya organisasi yang sangat mengikat dan ketat. Hal yang sama juga disampaikan oleh Waskito Hartono, ia masuk ke PUTM karena dorongan dari sang ayah. "Sebenarnya ayah saya yang pengen saya masuk

\footnotetext{
${ }^{2}$ Wawancara dengan Hudzaifaturahman (Udze). Musyrif PUTM. 9 Juni 2013. Udze adalah musyrif PUTM dan baru lulus dari PUTM pada tahun 2012. Dengan muka yang datar, Udze menjelaskana tentang budaya-budaya yang akan membetuk karakter para thalabah selama di PUTM.

${ }^{3}$ Wawancara dengan Alma Febriana F. 25 April 2013. Wawancara berlangsung di sebuah warung kopi. Sambil menikmati kopi pahit, Alma menceritakan pengalamannya dalam menjalani sunah pondok yang sudah menjadi kebiasaan di PUTM.
} 
di PUTM, kalau saya sih pengen kuliah di umum aja" begitu kata thalabah yang berasal dari Ciamis dengan mimik muka datar. Waskito juga tidak pernah menyangka akan melanjutkan jenjang pendidikan setelah lulus Madrasah Aliyah di PUTM ${ }^{4}$.

Informasi yang berbeda justru disampaikan oleh Budi Aditya Wardhana. Thalabah yang berasal dari Gunung Kidul ini sudah mengenal PUTM sejak lama. "Desa saya dulu pernah dijadikan tempat Mubaligh Hijrah dari PUTM, jadi saya sudah lama tau PUTM dan memang pengen masuk ke PUTM". Budi juga mengatakan bahwa kebiasaan-kebiasaan yang ada di PUTM tidak seketat pondoknya pada saat di Aliyah bahlan di PUTM bisa lebih bebas ${ }^{5}$.

Dalam proses sosialisasi budaya organisasi, pengelola PUTM dibantu oleh pendamping yang melakukan beberapa pendekatan kepada thalabah dari mulai mereka masuk menjadi thalabah PUTM sampai mereka lulus. Secara garis besar, sosialisasi budaya organisasi menerapkan model pembelajaran long life education yang diturunkan kepada beberapa cara. Seperti yang disampaikan oleh Muhajir:

“..long life educations maksudnya setiap apapun yang thalabah lalukan adalah pendidikan bagi mereka. Seperti ada seorang thalabah yang melakukan kesalahan, akan langsung ditegur dan bisa menjadi pembelajaran bagi thalabah yang lain. Maksudnya adalah, dari situ para thalabah bisa melihat apa-apa saja yang bisa dilakukan dan sesuai dengan PUTM dan apa-apa saja yang tidak patut dilakukan dan tidak sesuai di PUTM.."

(Ahmad Muhajir, Wakil Mudir dan Pamong PUTM. 4 Juli 2013)

Cara pendamping melakukan sosialisasi budaya organisasi dengan dua jalur, yaitu jalur formal dan jalur informal ${ }^{6}$. Jalur formal dilakukan ketika pengelola PUTM memperkenalkan apa saja yang sudah menjadi kebiasaan-kebiasaan di PUTM. Pada awal masuk di PUTM, para thalabah akan dikumpulkan terlebih dahulu, kemudian pengelola memberikan secarik kertas berisi apa yang boleh dan tidak boleh dilakukan di PUTM. Kontrak tersebut kemudian dibaca dan dipahami oleh para thalabah. Setelah dibaca dan dipahami, akan muncul kontrak belajar yang disepakati oleh para thalabah. Kontrak belajar itu semacam akad atau bai'at yang akan menjadi pengikat antara PUTM dengan thalabah.

Temuan data penelitian di atas sangat jelas bahwa langkah awal pengelola PUTM dalam mensosialisasikan budaya organisasi menggunakan komunikasi formal karena dalam komunikasi formal salurannya ditentukan oleh struktur yang telah direncanakan dan tidak dapat dipungkiri oleh organisasi. Selain itu, terlihat jelas bahwa pesan yang mengalir melaui jalur resmi dan ditentukan oleh hierarki resmi organisasi dalam hal ini adalah pamong yang merupakan representasi dari pengelola PUTM.

Komunikasi formal ini sangat berfungsi penting dalam sosialisasi budaya organisasi di PUTM. Seperti yang dijelaskan Liliweri (1997: 284) bahwa fungsi komunikasi formal sebagai fasilitas untuk mengkoordinir kegiatan pembagian kerja dalam organisasi. Di PUTM pembagian wilayah peran dapat memperjelas batas peran antara para

\footnotetext{
${ }^{4}$ Wawancara dilakukan pada 5 Juni 2013 di kampus PUTM.

${ }^{5}$ Wawancara dilakukan pada tanggal 1 Juni 2013 di kampus PUTM.

${ }^{6}$ Wawancara personal dengan Endi, pendamping thalabah. 4 Juli 2013. Dengan kalimat yang sistematis disertai dengan gerak tangan, endi menjelaskan tentang pengenalan budaya organisasi PUTM kepada thalabah.
} 
Diterbitkan oleh Program Studi IImu Komunikasi

Universitas Ahmad Dahlan Yogyakarta

pendamping dengan thalabah. Pendamping berperan subjek pembinaan dan thalabah berperan sebagai objek pembinaan.

Fungsi lain dari komunikasi formal adalah secara langsung hanya meliputi hubungan antara atasan dengan bawahan. Komunikasi langsung seperti ini memungkinkan dua pihak untuk berpartisipasi umpan balik secara cepat. Dalam konteks PUTM, pada saat para thalabah menyepakati kontrak yang diajukan oleh pengelola PUTM, dimana terdapat interaksi secara langsung yang dilakukan diantara kedua belah pihak. Thalabah dapat memberikan umpan balik secara langsung ketika pengelola menyampaikan pesan yang berupa kontrak selama manjadi thalabah PUTM.

Adanya pendekatan komunikasi formal yang terkesan kaku diberikan oleh para pendamping justru menimbulkan grapvine atau desas-desus di kalangan para thalabah. Seperti yang disampaikan oleh Andi Muhammad Ikhwan Nur ${ }^{7}$ (Ikhwan) dan teman-teman satu angkatannya yang merupakan thalabah PUTM angkatan 2012. Ia menjelaskan surat perjanjian atau bai'at diberikan pada saat thalabah sudah menjadi mahasiswa PUTM. Ikhwan juga menambahkan, PUTM kurang transparan dalam menginformasikan konsekuensi ketika sudah menjadi thalabah PUTM, sehingga para calon thalabah tidak bisa mempersiapkan diri dengan baik ketika menghadapi kebiasaan dan nilai-nilai yang ada di PUTM. Dengan kata lain, Ikhwan mengungkapkan kekecewaannya karena tidak ada pengenalan atau sosialisasi sebelumnya tentang sosialisasi budaya yang akan dijalaninya selama menjadi thalabah PUTM.

Melihat temuan grapvine yang berkembang dikalangan thalabah ini, peneliti segera melakukan konfirmasi kepada salah satupendamping. Namun pernyataan yang berbeda disampaikan oleh salah satu pendamping yaitu Rohmasnyah, dia menyatakan bahwa ada sosialisasi budaya organisasi pada saat PUTM mengadakan perekrutan thalabah baru. Sehingga para calon thalabah bisa mempersiapkan diri dalam menghadapi kehidupan di PUTM. Pernyataan Rohmansyah dibenarkan oleh Syarif, bahwa ada sosialisai budaya organisasi PUTM pada saat wawancara. Namun budaya organisasi tersebut disosialisasikan tidak secara mendetail dan hanya secara garis besar.

“.. awalnya ya agak kaget mas setelah tahu secara detail apa yang boleh dan tidak boleh dilakukan di PUTM, tapi setelah diberi penjelasan sama pendamping ya bisa menerima..ada jargon yang diusung sama PUTM yaitu tidak ada kewajiban masuk PUTM, tapi setelah anda masuk PUTM maka wajib mengikuti apa yang sudah menjadi kebiasaan di PUTM. ini bisa kita analogikan seperti tidak ada kewajiban masuk ruang berAC tapi setelah kita masuk ruangan tersebut maka kita tidak boleh merokok.." (Syarif, Thalabah PUTM. 25 September 2013)

Selain terjadi keterkejutan, dengan adanya komunikasi formal tersebut menimbulkan sikap keterpaksaan oleh bebrapa thalabah. Rasa terpaksa dialami oleh Imam Reza Muzakki (Reza) dan Arief Rakhman Ajie (Ajie) ${ }^{8}$. Mereka merasa terpaksa mengikuti

\footnotetext{
${ }^{7}$ Ditemui di lokasi Mubaligh Hijrah di daerah Banguntapan pada tanggal 29 Agustus 2013, Ikhwan menceritakan tentang awal masuk di PUTM dengan wajah yang cerah seusai shalat tarawih. Ikhwan memang dari awal ingin memperdalam ilmu agama, maka dari itu seusai menempuh jenjang pendidikan di Madrasah Aliyah Agama, Ikhwan melanjutkan studinya di PUTM.

${ }^{8}$ Reza thalabah tingkat pertama PUTM. Reza merasa dijebak oleh orang tuanya ketika dimasukkan ke PUTM. Pada minggu-minggu pertama berada di PUTM, Reza sempat mengabarkan kepada orang bahwa tidak betah dan ingin keluar dari
} 
cara hidup di PUTM. Dalam keseharian di PUTM mereka menjalankan tidak sepenuh hati, dia merasa terkekang dan dipaksa untuk kebiasaan-kebiasaan yang ada di PUTM. Contohnya dalam mengenakan pakaian, tidak diperkenankan lengan pendek pada saat Shalat dan tidak boleh mengenakan celana berbahan jeans selama di PUTM. Selain itu juga, mereka pada tahun pertama mereka masih berat bangun pada dini hari untuk melakukan shalat malam dan juga puasa Senin dan Kamis.

Temuan observasi peneliti secara partisipator yang cukup mengejutkan adalah dengan munculnya konflik ini menimbulkan dua kelompok thalabah, yaitu thalabah yang bisa menerima budaya organisasi dan belum bisa menerima budaya organisasi. Kelompok yang belum bisa menerima budaya organisasi adalah para thalabah yang sebelum masuk PUTM berasal dari sekolah umum (SMA/SMK) dan kelompok yang bisa menerina budaya organisasi adalah para thalabah yang berasal dari sekolah keagamaan (Madrasah Aliyah Keagamaan) atau pondok pesantren.

Apabila peneliti merujuk pada proses sosialisasi budaya organisasi, pada tahapan yang demikian, thalabah sedang memasuki masa Encounter (Pertemuan). Inilah saatnya membuat kejutan saat pendatang baru memasuki teritorial yang tidak dikenal. Selama tahap encounter, individu ditantang untuk menyelesaikan konflik apa pun antara pekerjaan dan kepentingan di luar. Dalam tahap ini terjadi banyak konflik yang terjadi, karena thalabah mau tidak mau meninggalkan cara hidupnya sebelum masuk di PUTM dan harus mengikuti cara hidup yang ada di PUTM.Robbins, (2003) mengatakan pada fase seperti ini, para thalabah sedang masuk pada tahap perjumpaan suatu proses sosialisasi. Di organisasi ini seorang anggota baru melihat seperti apa sebenarnya organisasi yang dimasukinya. Pada proses ini individu kemungkinan akan menghadapi perbedaan antara harapan dengan kenyataan. Sama halnya yang terjadi oleh thalabah yang sedang mengalami proses adaptasi dengan cara hidup yang ada di PUTM. Maka dari itu, menjadi lumrah apabila terjadi gap antara thalabah yang dapat beradaptasi dan yang tidak dapat beradaptasi.

Dari temuan data di atas, peneliti melihat bahwa terjadi pemaksaan antara para pendamping kepada thalabah. pemaksaan ini semakin memperjelas bahwa komunikasi formal yang terjadi merupakan komunikasi formal vertikal dari atas ke bawah (top down). Komunikasi ke bawah dalam sebuah organisasi berarti bahwa informasi mengalir dari jabatan berorientasi lebih tinggi kepada mereka yang berotoritas lebih rendah. Komunkasi ke bawah digunakan untuk menyampaikan pesan-pesan yang berkenaan dengan tugastugas dan pemeliharaan dalam rangka mewujudkan tujuan organisasi. Pesan tersebut biasanya berhubungan dengan pengarahan, tujuan, disiplin, perintah, pertanyaan dan kebijaksanaan umum.

Terjadinya penolakan oleh thalabah menjadi hal yang lumrah dalam komunikasi ke bawah ini. Karena dalam komunikasi ke bawah bertujuan untuk mengubah sikap thalabah yang pada awalnya belum terbiasa dengan cara hidup PUTM. Menurut Lewis (dalam Muhammad, 2007: 108), komunikasi ke bawah adalah untuk menyampaikan tujuan, untuk merubah sikap, membentuk pendapat, mengurangi ketakutan dan kecurigaan yang

PUTM, tetapi orang tuanya tidak menghendaki. Reza sering pura-pura sakit untuk menghindari perkuliahan terutama mata kuliah yang menggunakan kitab gundul yang belum pernah ia pelajari sebelumnya karena bukan berasal dari pondok pesantren. Sementara Ajie thalabah tingkat dua PUTM, motivasi Arief masuk di PUTM karena latar belakang ekonomi keluarganya yang kurang mampu. 
Diterbitkan oleh Program Studi IImu Komunikasi

Universitas Ahmad Dahlan Yogyakarta

timbul karena salah informasi, mencegah kesalah pahaman karena kurang informasi dan mempersiapkan anggota organisasi untuk menyesuaikan diri dengan perubahan.

Sementara itu, komunikasi informal yang dilakukan oleh pendamping dibagi menjadi beberapa cara. Cara pendekatan informal yang pertama adalah dengan pencernaan indrawi ${ }^{9}$ para thalabah. Cara ini adalah dimana para thalabah yang baru masuk PUTM mencerna pesan melalui indra mereka dengan melihat para kakak kelas. Contohnya dalam melaksanakan sunah-sunah pondok yang menjadi tradisi di PUTM. Para kakak kelas mengenakan lengan panjang dan peci pada saat shalat, maka para thalabah baru juga dengan sendirinya akan mengikuti apa yang mereka cerna secara indrawi dari perilaku kakak kelas. Contoh lain adalah ketika ada kakak kelas yang mendapatkan hukuman karena melakukan pelanggaran atau kesalahan, maka dari situ para thalabah baru akan mengetahui apa yang boleh dilakukan di PUTM dan apa yang tidak boleh dilakukan di PUTM.

Pencernaan indrawi dirasakan oleh thalabah yang baru masuk menjadi mahasiswa di PUTM. Seperti yang disampaikan Riduan Hadi Pranata ${ }^{10}$ (Riduan), alumni PUTM yang sekarang mengabdi menjadi musyrif di Mua'alimin Muhammadiyah. Riduan menyatakan bahwa dia sangat terbantu dalam menyesuaikan cara hidup di PUTM dengan melihat para kakak kelas dan musyrif pada saat awal masuk PUTM. Riduan mengakui, ada paksaan pengelola dalam menjalani cara hidup di PUTM seperti kewajiban shalat malam dan puasa Senin Kamis, tetapi karena ada contoh dari kakak kelas dan para musyrif Riduan merasa terbantu dalam beradaptasi di PUTM.

Cara komunikasi informal yang kedua adalah melakukan pendekatan secara kelompok dan personal kepada thalabah. Pendekatan kelompok menurut Rohmasyah dilakukan pada saat musyrif melakukan pertemuan dengan para thalabah seusai shalat walau tidak rutin. Musyrif memberikan stimulus yaitu berupa motivasi dan juga cerita tentang pengalaman-pengalaman terdahulu di PUTM yang dapat memberikan inspirasi bagi para thalabah untuk meningkatkan religiusitas. Contohnya dalam pengkondisian kelas pada saat muroja'ah (belajar), dresscode pada saat perkuliahan, komitmen untuk meningkatkan spiritualitas dan lain sebagainya. Cara ini dia dapatkan dari pengalamannya pada saat menjadi thalabah PUTM. Pada saat itu, Alm. Ustad Suprapto Ibnu Juaraim ${ }^{11}$ sering mengumpulkan thalabah dan mengisinya dengan tausiyah tentang cerita-cerita Nabi dan para sahabatnya yang bisa menyentil pelanggaran yang dilakukan oleh thalabah.

Sementara pendekatan personal biasanya dilakukan pada saat thalabah melakukan pelanggaran. Thalabah yang bermasalah diajak untuk berkomunikasi empat mata di ruang musyrif, kemudian musyrif menanyakan kenapa thalabah tersebut bisa bertindak demikian. Apabila masih tidak bisa berubah, biasanya musyrif dan pamong melakukan musyawarah, bagaimana seharusnya yang dilakukan. Namun apabila dirasa masih susah untuk

${ }^{9}$ Penggunaan kalimat "pencernaan Indrawi" peneliti gunakan untuk menjelaskan tentang pencernaan pesan dengan panca indra para thalabah PUTM dalam menerima sosialisasi budaya organisasi dari kakak kelas.

${ }^{10}$ Ditemui pada saat berkunjung ke PUTM tanggal 4 Juni 2013, Riduan menceritakan tentang pengalamannya selama manjadi thalabah di PUTM.

${ }^{11}$ Alm. Ustad Suprapto Ibnu Juaraim adalah mantan Mudir PUTM yang dikenal tegas namun dekat dengan para Thalabah. Pada masa kepemimpinannya, nuansa pondok pesantern di PUTM sangat kental, karena dahulu PUTM adalah pondok pesantren yang masih menggunakan sistem manajemen pendidikan tradisional, seperti tidak ada ijasah legal formal dan belum menggunakan alat transaksi modern. Namun setelah beliau meninggal dan digantikan oleh Ustad Saad Abdul Wahid, manajemen pendidikan di PUTM disetarakan dengan perguruan tinggi, ada ijasah legal formal dan sudah menggunakan alat transaksi modern. 
mengatasinya, para musyrif dan pamong memanggil thalabah yang bersangkutan untuk diajak bicara. Dalam forum tersebut, para musyrif dan pamong menanyakan kembali kepada thalabah tentang komitmen yang telah disepakati pada awal masuk PUTM. Kalau memang masih belum bisa dan mengulangi kesalahannya lagi, maka atas izin mudirmusyrif akan lakukan pemanggilan orang tua. Jikalau kalau masih belum bisa berubah maka thalabah dipersilahkan untuk meninggalkan PUTM.

“..kami pernah menemukan thalabah yang hipokrit jadi kalau anak itu kami nasehatin malah marah-marah. Jadi kami lakukan pemanggilan terhadap orang tua thalabah, ternyata memang dia kalau dirumah memang begitu...."

(Ahmad Muhajir, Pamong PUTM. 4 Juli 2013)

Rohmasyah ${ }^{12}$ mengakui, tidak mudah untuk mesosialisasikan budaya yang sudah ada di PUTM kepada thalabah baru. Dia berpendapat, pendekatan personal lebih ampuh dalam mensosialisasikan budaya organsiasi, karena apabila tidak dilakukan pendekatan personal terkadang thalabah tidak bisa menerima secara langsung atau bahkan berontak. Rohmasnyah bisa merasa demikian karena dia pernah merasakan sebagai thalabah di PUTM. Maka dari itu tugas Rohmansyah sebagai pendamping bisa menyadarkan para thalabah tentang mengapa praturan dibuat sedemikian rupa.

Pendekatan dengan komunikasi informal dengan personal dapat menimbulkan deketan antara thalabah dan pendamping secara intim karena arah informasi yang terjadi yang muncul bersifat pribadi yang muncul interaksi diantara kedua belah pihak dan mengalir keseluruh organisasi tanpa dapat diperkirakan. Dengan adanya kedekatan personal ini dapat memperkecil adanya kebingungan, kesalahpahaman, penyimpangan atau perubahan lainnya yang disengaja(Pace dan Faules, 2010: 202).

Pendekatan komunikasi informal yang ketiga adalah penekanan sosok panutan, dijelaskan oleh Muhajir cara ini lebih menekankan pembinaan tentang kesadaran sebagai figur yang dewasa dan dilakukan pada saat thalabah memasukin tahun ketiga. Dengan figur yang dewasa apa yang mereka kerjakan akan menjadi panutan bagi adik tingkatnya. Pada tingkat tiga para thalabah sudah memasuki tahun terakhir dan sudah menjadi uswatuh hasanah (contoh yang baik) bagi adik-adik tingkatnya ${ }^{13}$.

Begitu juga yang dirasakan oleh Ahmad Syarif (Syarif) ${ }^{14}$. ketika berada di tingkat ke tiga atau tingkat akhir, dia harus memberikan contoh kepada adik kelasnya bagaimana menjalankan nilai-nilai budaya di PUTM. Dia merasa malu apabila melakukan pelanggaran, karena sekecil apapun pelanggaran yang dilakukannya akan menjadi contoh bagi adik-adik kelasnya. Syarif semaksimal mungkin untuk tidak melakukan pelanggaran dari hal yang mungkin dianggap sepele, seperti bangun tepat waktu pada saat shalat malam, mengenakan baju lengan panjang pada saat shalat dan juga masuk kelas tepat waktu.

\footnotetext{
${ }^{12}$ Matanya yang nanar, menyiratkan Rohmansyah menyimpan kekhawatiran yang mendalam kepada anak didiknya itu.

${ }^{13}$ Sambil mengerutkan alis mata, Muhajir menceritakan tentang bagaimana peran thalabah tingkat tiga yang menjadi suri tauladan bagi adik kelasnya.

1425 Mei 2013, ditengah riuhnya suasana warung kopi dan ditemani tembang klasik milik Iwan Fals yang didendangkan oleh pengamen, kami melakukan perbincangan santai tentang pengalaman Syarif selama manjalani romantika kehidupan di PUTM.
} 
Diterbitkan oleh Program Studi IImu Komunikasi

Universitas Ahmad Dahlan Yogyakarta

Dalam fase sosialisasi budaya organisasi, pada saat-saat tersebut thalabah sudah masuk dalam tahap metamorfosis. Adanya kesadaran untuk memberikan contoh kepada adik kelasnya merupakan proses akhir dari sosialisasi budaya organisasi. Hal tersebut tidak bisa lepas dari peranan langsung dari pendamping dalam tahap perubahan dan pemahaman yang bertambah. Pada tingkat akhir tersebut thalabah telah masuk pada tahap metamorfosis, pada tahap ini anggota baru menyesuaikan diri pada nilai-nilai dan norma kelompok kerjanya (Robbins, 2003).

\section{E. Kesimpulan}

Setelah melakukan penelitian di PUTM tentang sosialisasi budaya organisasi, tahapan sosialisasi budaya organisasi yang disampaikan oleh Robbins (2003) yaitu tahap pra kedatangan, tahap pertemuan dan tahap metamorphosis terjadi di PUTM. Ini membuktikan bahwa teori tentang tahapan sosialisasi budaya organisasi Robbins juga dapat terjadi di organisasi pondok pesantren seperti PUTM. Namun yang perlu diketahui dalam sosialisasi budaya organisasi di PUTM banyak terjadi fenomena-fenomena komunikasi yang terjadi terutama pada tahap pertemuan. Berbagai cara pengelola PUTM dalam mensosialisasikan budaya organisasi, bahkan sempat terjadi penolakan dari thalabah yang mengalami keterkejutan budaya atau sock culture karena belum terbiasa dengan kebiasaan-kebiasaan atau budaya yang ada di PUTM. Namun walau seperti itu, sosialisasi budaya organisasi yang dilakukan oleh pengelola PUTM dapat menjadikan para thalabah beradaptasi dengan budaya organisasi PUTM.

\section{Daftar Pustaka}

Laksmini, Asri, R. 2011. Budaya Organisasi. Yogyakarta: Graha Ilmu.

Liliweri, Alo. 1997. Sosiologi Organisasi. Bandung: PT. Citra Aditya Bakti.

Liliweri, Alo. 2004. Wacana Komunikasi Organisasi. Bandung: CV. Mandar maju.

Muhammad, Arni. 2007. Komunikasi Organisasi. Jakarta: Bumi Aksara.

Robbins, Stephen, P. 2003. Organizational Behaviour, Tenth Edition. New Jersey Prectice Hall.

Salim, Agus. 2006. Teori dan Paradigma Penelitian Sosial : Buku Sumber Untuk Penelitian Kuanlitatif. Yogyakarta: Tirta Wacana.

Pace, R Wayne\&Faules, Don, F. 2010. Komunikasi Organisasi: Strategi Meningkatkan Kinerja Perusahaan. Terjemahan: Deddy Mulyana. Bandung : Remaja Rosda Karya.

Wirmer, Roger D \& Dominick, Josep R. 2006. Mass Media Researc an Introductions. Australia: Tomshon.

Yin, Robert K. 2004. Studi Kasus, Desain dan Metode. Jakarta: Raja Grafindo. 
